\title{
Plato's Theories of Knowledge and Education: an Examination of the Interpretations of Cloete and Agyemang
}

\author{
*H. M. Majeed \\ http://dx.doi.org/10.4314/ujah.v15i1.1
}

\begin{abstract}
The question of what knowledge is about or what it means to know often ends up as one of whether or not knowledge of something, indeed, of all things can really be taught. Some of the most insightful responses to these questions in ancient Greek philosophy can be found in the intellectual context between the Sophists and Plato in the $5^{\text {th }}$ century BC. Unlike the Sophists, Plato held the view, for instance, that 'true knowledge' (epistême) could not be taught. This point is recognized by both Michael Cloete and Kwasi Agyemang in their individual interpretations of Plato. While generally accepting Agyemang's analysis of Plato's views, this article reveals some serious logical and factual errors in Cloete's interpretations, and thereby clarifies Plato's epistemology and theories of education.
\end{abstract}

\section{Plato on knowledge and education}

In the $5^{\text {th }}$ century Athens was a group of philosophers ('wise men') who claimed to equip people, mostly the youth, with knowledge related to various fields of study. They also presented themselves as teachers of the art of argumentation (and rhetoric) and, thus, as masters of wisdom. Members of this group of philosophers are commonly referred to as the Sophists. Plato disagreed 
with them on most of their claims and methods, and in so doing introduced some of the most insightful theories of knowledge that continue to influence the thinking of modern writers on education and epistemology. For instance, Plato's ideas on the nature of human knowledge and his disagreement thereof with the Sophists constitute the thrust of Cloete's article ${ }^{1}$ which, incidentally, is a subject of discussion of this piece.

Plato invests the soul with epistemic attributes. The immortal soul, according to him, on its own, once had knowledge of certain concepts prior to its 'imprisonment' in the human body. ${ }^{2} \mathrm{He}$ also conceives of the soul as having had access to the world of Forms (eidos) and, thus, as having knowledge of the perfect objects (or concepts) in that world (Phaedo 102ff). This knowledge, termed epistême, is regarded by Plato as true, eternal and perfect, taking after the attributes of the Forms. It is this knowledge that a person recollects anytime he or she reaches to the soul (Meno 81c-d) - as demonstrated by Plato with the uneducated slave-boy Meno - using such appropriate methods as the dialektikos. Thus, epistêmic knowledge is presented as something which is known to and derived by each individual's own self (soul), in contrast with the opinions which a person forms of his or her sensations, or with received ideas of others. Two kinds of 'knowledge' are hereby, respectively, established: viz. epistême and doxa. ${ }^{3}$ Even though doxa is 'the general word for "belief", [it] tends to carry with it the hidden, but sometimes operative, implication that the belief in question is an assessment of something. This is an 
important clue to the contrast of doxa with epistême ... for epistême implies that the object is not being interpreted, but grasped [by the mind]' (Crombie 1963: 34 , my square brackets).

Closely related to the distinction between epistême and doxa is the distinction Plato makes between two kinds of virtues: (i) ordinary virtues [which, according to him are not far removed from bodily qualities' (Republic VII: 518-519)] such as temperance and courage, and (ii) wisdom [which is a 'virtue of some diviner faculty' (ibid: 519)]. He regards the former, unlike the latter, as the ones that can be taught or 'reproduced by habituation and exercise' in someone who lacks them (ibid: 518519). Thus, he conceives of wisdom as associated with knowledge of the Good and exhibited in the actions and thoughts of the righteous or philosopher. And, since knowledge of the Good is self-acquired, it could be said that Plato associates wisdom with epistême and ordinary virtues with doxa. Secondly, Plato seems to suggest with the example of wisdom that it is possible to know something (epistemically) without having the expertise or ability to teach it to others. This point is clearly made in Protagoras 319e. I reckon, though, that Plato sometimes does not intend to show the difference between the two groups of virtue (as found in Laws 10.906b; Republic IV: 427c-434d).

With regard to education, two broad forms can be distinguished. One involves the imparting of true belief in the form of (i) lessons drawn from poetry, legends and myths for the moulding of children's character, (ii) non- 
philosophic literary education which is meant for the development of the mind, and (iii) physical education of the body (Republic II:376e-III:412b). This set of education is distinguished from epistême-oriented education in which, for instance, a philosopher, with some preliminary literary education, is able to self-know the forms or, as stated in the Republic (521e), perceive the Good. Plato also demonstrates with Meno that this knowledge can be acquired through anamnesis.

\section{Cloete's interpretation of Plato's epistemology}

Cloete's analysis of Platonic epistemology is good for a number of reasons. First, he explains how Plato attempts to account for certain concepts of epistemic value without giving in to either 'intellectual dogmatism' or 'intellectual defeatism' (Cloete 2011: 71, 80). One such concept is the soul. According to Cloete, the existence of the human soul is not seen by Plato as necessarily true or false - i.e., it is not known with certainty to human beings (ibid: 81). Therefore, Plato would not accept the view that one can claim knowledge of the existence of the soul without proof, neither would he advocate resigned acceptance of the impossibility of investigating the question. These two positions, I understand, are the basis for Cloete's claim of rejection of 'intellectual dogmatism' and 'intellectual defeatism' by Plato. Consequently, Cloete suggests, Plato attempts investigating the question by relying on the logical strength of some assumptions which he makes of the soul and its immortality. 
The resort to logical assumptions - a form of reasoning which Cloete terms 'the hypothetical mode of reasoning' - is applicable, in general, to all moral qualities which are also assumed to 'have an objective (ontological) dimension that precedes their concrete, empirical manifestation in society' (ibid: 76). As a result, a moral quality like virtue can only have 'an unreal' character in the empirical world, and thus cannot be taught by even the wisest of humans using the best practical, teaching skills (ibid).

By virtue of the above mentioned non-teachability of 'moral qualities', Plato's epistemology is portrayed as ensnarled with the notion of pedagogy or, in the least, with some pedagogical considerations. Another strength of Cloete's is that he discusses education (though not thoroughly) - as he does below - in relation to Plato's epistemology. For, knowledge or its acquisition is, most of the time, dependent on the availability and quality of education. What Cloete does not do, however, is paying sufficient attention to the subtleties in Plato's conception of education - leaving his analysis sometimes confusing or erroneous altogether.

\section{Problems with Cloete's Analysis}

To start with, some of Cloete's own arguments do not seem to add up. He argues, for example, that unlike the Sophistic view that to educate someone is to lead him or her eventually to 'individual success' in a specific field or subject of education, Plato advances that the education of any individual should serve a moral end: 'the common good'(ibid: 74). Accordingly, Cloete 
explains, "the moral education of the individual must ultimately serve the principle of justice in the political community' (ibid). What is noteworthy here is that by 'moral education' Cloete means 'virtue' (ibid). Yet, he affirms of Plato that virtue cannot be taught. ' If, indeed, virtue cannot be taught, how then can there be a 'moral education' of the individual? The only reasonable explanation to Cloete's position is either that Plato was theorizing different senses of education which Cloete paid little attention to, or that he probably writes his article on the assumption that his reader knows them already. Even here, it is still not clear why Cloete should fail to alert the reader of his assumption. In reality, however, the former alternative is, as explained in the first section of this essay, true of Plato.

Cloete also suggests that Plato would not accept that there could be a philosophical school, suggesting consequently that Platonism is inconsistent with the teachings of Plato (ibid: 70). But, to be able to appreciate the context in which Plato makes his point and to address the concerns raised by Cloete effectively, let me first attempt a summary of the relevant issues in the work which Cloete cites: Plato's Seventh Letter ${ }^{5}$ is largely a reaction to Dionysius II of Syracuse who published 'a treatise expounding Platonism'. ${ }^{6}$ Plato explains therein that the grasping of true knowledge is by the mind, and that whoever has such knowledge (of a concept or word) can cause another to have some level of knowledge or understanding (nous) of it if the latter is also made to have practical knowledge of the word, its definition, and material instantiations of it. This practical knowledge is 
obtained by the person when he or she is trained over a period. However, the trained person cannot claim 'real' knowledge of the concept because (i) words used in explaining it to him or her do not always mean the same, and (ii) the physical things used in demonstrating knowledge of the concept do not always have one noncontradictory nature. The case, Plato notes, is even worse for the untrained person (such as Dionysius II) who, unlike the trained person, is not in a position to have any 'true belief' about the concept. ['True belief' being the sort of 'knowledge' the trained person comes to possess.] Basically, however, Plato's refusal to claim to teach any true knowledge (of his) to any persons or students - either in his writings or sayings - seems to be as a result of his conviction that such knowledge, infallible knowledge, cannot be taught. Plato's reaction, therefore, amounts to this: that 'Words and instances cannot communicate knowledge; it is only by a laborious process of taking the pupil through and through these over and over again that knowledge can be brought about, and even then only in a man who has an affinity to the subject' (Crombie 1963: 123-4), and that 'however skillful we try to communicate the truth by language or the use of instances, what we say or point to is always liable to empirical confutation' (Crombie ibid: 124).

But, Cloete understands the following portion of the Seventh Letter to be Plato's rejection of the philosophical movement of Platonism:

One statement at any rate I can make in regard to all who have written or who 
may write with a claim to knowledge of the subjects to which I devote myself no matter how they pretend to have acquired it, whether from my instruction or from others or by their own discovery. Such writers can in my opinion have no real acquaintance with the subject. I certainly have composed no work in regard to it, nor shall I ever do so in the future, for there is no way of putting it in words like other studies (342c) [Cloete ibid: 70]

In the light of our earlier exposition one can understand how Cloete's interpretation of the preceding quotation might not be correct. It is critical that one takes notice of the significance of the expression 'no real acquaintance with the subject' in the quotation above. The expression is in relation to the impossibility to gain true knowledge - i.e., knowledge of the real nature or whatness of things, the concepts or, if you like, the Forms [Ideas] which he teaches in the Phaedo - solely on the basis of what one has heard Plato say or on account of what one makes of Plato's written ideas. A claim to knowledge of Plato's 'own knowledge' on either basis is, properly speaking, a claim to a knowledge degraded by language - and thus 'a pretence' to Plato's first-hand knowledge. This firsthand knowledge is what Plato does not see himself composing any work to teach, giving all the difficulties there are in connection with the use of language, in any attempt to transmit knowledge. It is impossible, Plato would argue, to know what he knows. 
However, it is a different issue if one puts forward what one has heard another person (for example, Plato) say without necessarily claiming infallible knowledge of what that person knows. This would be acceptable to Plato, especially if one avails oneself of some philosophical tutoring by the other. For, this is exactly the case between Socrates and Plato himself, and is the basis for the latter's lofty exposition of the former's philosophy in different dialogues. From every indication, however, Dionysius II was not modest in his claims - or so Plato thought of him. But if Plato could apparently present or espouse the views of Socrates, why would it not be possible for anyone else to do same about Plato? Why should Cloete suppose that Plato would contradict himself by insisting that this is impossible? It appears to me that if more than one person can do so about Plato, then, the emergence of a philosophical school is consonant with Plato's teachings. I will throw more light on this in due course. Yet, Cloete argues that the quotation from The Seventh Letter (342c) above is a clear rejection of Platonism (as in philosophical school) because of two reasons which, in any case, do not quite support his position. The reasons, which are the only major deductions he makes from that quotation (but does not explain), are:

(i) That Plato 'assumes' that there is 'a prelinguistic realm whose representation either in the form of spoken or written word can, at best, be an inferior copy of the perfect realm of Forms (Ideas)'. 
(ii) That in the view of Plato, there cannot be 'the possibility of "true" knowledge in matters of a metaphysical nature'. 7

By (i) above, Cloete seems to think that since Plato implies that objects of the Formal world can only be expressed imperfectly with spoken or written word, it would be inconsistent with this position of Plato's to suggest that there can be a philosophical school that presents the views of Plato about the Forms or concepts which he devotes himself to. But, it is evident from our analysis that Plato is not really concerned about whether his expressed views should at all be commented upon (by any individual or group of thinkers), which is what Platonism as a philosophical school is engaged in. Platonism, therefore, is not necessarily rendered impossible by the quotation (342c). The imperfection of the written or spoken word is only being recognized by Plato as a handicap to himself (and humankind, for that matter) in the explanation of 'things' (or concepts) that belong to the perfect world of Forms. The reason being that apart from the lack of precision mentioned in the Seventh Letter in relation to language and the empirical, the epistemic soul which alone is capable of knowing or perceiving clearly the metaphysical world of Forms, is not fully able to do so while it remained entrapped ('imprisoned', to use his words) in the imperfect, physical body and in this world. [In fact, the latter reason is the only context in which Cloete's remark in (ii) above can be made sense of.] Therefore, words formed of empirical things cannot adequately capture the nature of things in the Formal world. In connection with the 
above, there are some remarks that one cannot make about Platonism. By Platonism, I mean the philosophical school which is nothing but an abstract body consisting of philosophers dedicated to the interpretation of views expressed by or implicit in the expressions of Plato. One cannot remark that these philosophers (i) believe that they are not subject to the handicap recognized above by Plato, and (ii) claim that each member's explanation of Plato is perfect. But, since neither they nor Plato could engage in the art of philosophizing without learning about and analyzing the views of others, the idea of a philosophical school would, again, not quite be objectionable to Plato. Plato would not, therefore, reject their or any philosopher's attempt to understand or explain his expressed philosophical ideas. Were it not so, I wonder whether Cloete's very article would have been seen to contribute to knowledge and to be useful to students of philosophy - but it is.

Platonism may be understood as 'the philosophy deriving directly or indirectly from the work of Plato' or as 'a commentary on complexities in Plato's own thought' (Flew 1979: 272) or as the transcendental doctrines of Plato, or simply as a movement (philosophical school) in the sense discussed above. It is noticeable that while the first three are about ideas (or doctrines), the last one is about people - the people engaged in the expression of especially the first two ideas. Thus, the first three are a basis for the formation of the fourth, but cannot be labeled or characterized as the same as the fourth. Yet, Cloete writes of Plato's philosophical doctrines - he refers to them also as a 
'philosophical system' - as if they constitute a movement, although only human beings can constitute a movement. In his unsuccessful attempt to reject Platonism, he makes an inference which suggests this: that there is

... a deep-seated assumption that Plato's body of writing (his dialogues and letters) represent a set of philosophical letters and doctrines (a philosophical system) that can neatly be identified and labeled as a philosophical school or movement (of Platonism), which he has himself emphatically denied. ${ }^{8}$

Further analysis of Cloete will be made at the right places in the next section.

\section{Agyemang's interpretation of Plato's epistemology}

Consistent with our earlier interpretation of the Meno, Plato's demonstration with Meno is seen by Agyemang as indicative of a kind of education. That, knowledge (epistême) which is self-acquired and neither given by another nor acquired through sensation, is produced only by what he (Agyemang) admits is 'true education' and calls it paideia. Agyemang distinguishes this paideia from 'dative instrumental education' which is the sort that feeds the student with the accepted ideas on a subjected matter or in a field of professional studies which are required by the student to function well in that profession or in society. ${ }^{9}$ This latter education, according 
to him, produces at best only endoxa (belief) or doxa alethes (true belief). As he notes:

Plato emphatically distinguished Epistême from Endoxa. This was meant to reinforce his strong unyielding position on the difficult nature of knowing Knowledge even to the exclusion of doxa alethes from being identified with Epistême (Agyemang 1987: 52).

Indeed, Plato also argues that true knowledge entails more than true judgement that comes with its rational justification (Meno 97e; Symposium 202a). And, for Agyemang, Plato would reject the position, as he did in the Theaetetus, that a person who 'receives logos in addition to his doxa' has epistême because lógos is 'not received but [self-] suffered' (Agyemang ibid: 56; square brackets added). Therefore, any form of education specifically, of dative instrumental education purporting to provide a person with lógos plus doxa is not 'true education'. He calls such education 'unreal' or 'sophistic' or 'coercive' education. Finally, he affirms at several places that while the knowledge gained from paideia is not teachable, that from dative instrumental education is teachable. For instance, he maintains that:

Unlike Plato, however, Epistême, in Aristotle's hands, became 'science', but 'science' is not, for Plato Epistême proper, but, at least, doxa alethes. For, it is teachable and transmittable; and by syllogismus many can get it or avail 
themselves of it somehow. Here, knowledge is not Epistême, but science, molded as demonstration, involving a passage from First Principles to arriving at conclusions. Just as Epistême as Knowledge, true knowledge, is Platonism, Epistême, as science, is Aristotelianism, but the latter is grounded upon the former (Agyemang ibid: 52).

... knowledge proper is a matter of selfactivity, involving direct, immediate and intuitive vision of reality itself, to obtain which one is on one's own and not suffered by one for another but by one, for one, in one and through oneself ... It cannot be taught, loaned, donated or borrowed, nor is it transmittable in any way ...( Agyemang ibid: 54)

Knowledge is a Task, it is selfadventured, self-won, not passed on (Agyemang ibid: 55)

The account given above of Agyemang enables us to make some few additional remarks about Cloete:

(i) That his suggestion that we are cautioned by Plato that if education "falls into the "wrong hands", it poses a threat to the possibility of the type of knowledge required for serving 
the interest of society as a whole' (Cloete ibid: 73) require further explanation. $\mathrm{He}$ seems to use 'education' in line with the way Plato used the term in connection with the activities of the Sophists - i.e. 'education' via instruction. In the sense used by Cloete, therefore, 'education' should, in comparison with Agyemang's analysis, be understood only in the context of dative instrumental education.

(ii) That given his earlier rejection of Platonism, Cloete's observation that Plato 'emphasises $a$ priori knowledge of the Forms (Ideas) of knowledge which we necessarily presuppose in any philosophical enquiry' (ibid: 78) is questionable indeed. One can hardly tell who he does refer to as 'we', and how 'any philosophical enquiry' does become or involve a presupposition of the Forms (Ideas). Without doubt, many philosophical enquiries especially in empiricism and existentialism would neither recognize nor presuppose 'the Forms' (or their associated knowledge type).

\section{Conclusion}

Plato conceives of the soul in epistemic terms in the Meno and Republic, just as he does in the Phaedo where the soul is presented as immortal and capable of accessing the world of Forms. Plato, thus, distinguishes 
knowledge concerning the world of Forms (epistême) from that acquired through sensation (doxa). He sees the latter as teachable while the former is not. We have explained that, unlike Agyemang, Cloete's interpretation of Plato's epistemology falls short of clarity, due to his inability to pay sufficient attention to these concepts even within the limited scope of the specific works of Plato which he cites.

\section{Notes:}

1. Although the title of his article mentions neither knowledge nor education, these two concepts form part of the core issues he deals with.

2. See Meno 81c-d; the need for the soul's 'escape' from the body in order for it to reflect on or have more of such knowledge is found in 'Phaedo' 6566a. And, the idea of imprisonment is also captured in The Republic: VII.

3. In such works as Gorgias and Republic, Plato originally uses pistis for doxa.

4. Cloete (ibid: 75, 76) cites Protagoras 320 b.

5. See particularly section 341-344.

6. Crombie $(1963,122)$ captures very well Plato's position on the issues discussed in this paragraph.

7. Cloete (ibid:70-71) deduces these two statements from Plato's Seventh Letter 341c.

8. Cloete (ibid:70); he does not show how such 'identification and labeling' are done.

9. Agyemang (1987: 148, 149); his work is largely about the relevance of Plato's metaphysics to the progress of the human being and society. He sees 
this progress to be dependent on human creativity; a 'natural' task which he thinks is best performed through the acquisition of epistême and 'true education'.

H. M. Majeed is of the Department Philosophy \&

Classics, University of Ghana

\section{References:}

Agyemang, Kwasi, The eclipse of nature and the sophistry of being and knowledge: Hermeneutical research into problems of knowledge and being, Toronto: Emerson House, 1987.

Cloete, Michael, 'Plato's debate with the Sophists: The hypothetical mode of Reasoning', Phronimon 12, 2, 2011, 69-84.

Crombie, Ian M., An examination of Plato's doctrines, London: Routledge \& Kegan Paul, 1963.

Flew, Anthony (ed.), A dictionary of philosophy, New York: St. Martin's, 1979.

Plato, The Republic of Pato, Cornford F.M. (trans.), Oxford: Oxford University Press, 1945.

Plato, 'Phaedo', in EdithHamilton and Cairns (eds.), The Collected Dialogues of Plato, New York: Bollingen Foundation 1961: 40-98.

Plato, Meno, Anastaplo, G. and Berns, L. (trans.), Newsburyport, MA: Focus Publishing, 2004.

Plato, Symposium, Waterfield, Robin (trans.), Oxford: Oxford University Press, 2009. 